\title{
Performance-Based Funding: Equity Analysis of Funding Distribution among State Universities
}

\author{
Robin Ann Ellis (Corresponding author) \\ Corpus Christi in Education Leadership Program, College of Education \\ Texas A\&M University, TX 77843, USA \\ E-mail: robin.ellis@tamucc.edu
}

Received: April 11, 2015 Accepted: July 12, 2015 Published: July 16, 2015

doi:10.5296/jei.v1i2.7412ＵRL: http://dx.doi.org/10.5296/jei.v1i2.7412

\begin{abstract}
How to finance higher education remains controversial among policy makers and constituencies across the United States. Texas is not exempt from the controversy. With increasingly strained state finances, institutions of higher education and the Texas Higher Education Coordinating Board (THECB) have come under pressure to increase performance accountability, efficiency, and competitiveness. In Texas, House Bill 9 (H.B. 9) was enacted in 2011 to dedicate a portion of state funding to public colleges and universities that meet specific performance-based standards. Although H.B. 9 has been passed and signed into law, it still has not been determined how funding will be distributed or how effective it will be. This paper analyzes data from several states with similar performance-based funding standards to help bring to light to the possible effects H.B. 9 will have on Texas' public four-year universities.
\end{abstract}

Keywords: Policy, Accountability, Performance-based funding, Texas higher education

\section{Introduction}

Higher education is considered essential in serving the public good by contributing to the growth of the American society (Cohen \& Kisker, 2010). More recently, public higher education is increasingly required to defend, justify, and validate its performance and value to legislators, taxpayers, and society in general. The past several years have been exceptionally difficult on colleges and universities as declines in state appropriations are offset by increased student fee revenue. Much of the decline can be attributed to the shifting paradigm of how public funding is allocated to institutions of higher education (McLendon \& Hearn, 2013).

The trend among policymakers is to move away from the reliance on enrollment-driven funding formulas toward policies that link appropriations to an institution's ability to 
document state mandated educational performance-based standards and results (Miao, 2012). Historically, colleges and universities received state funding based on how many full time equivalent students enrolled at the beginning of a semester. However, states are now reconsidering the enrollment-based funding model because, though it provides incentives for institutions of higher education to enroll students, it does not offer incentives for institutions to help students successfully complete degree programs (NCSL, 2014). State policy makers are progressively linking this funding model to accountability and efficiency outcomes that directly impact the needs of students, the state, and the economy (Rabovsky, 2014). However, initial data challenges the success of performance-based legislation for higher education (Rabovsky). Since higher education is frequently viewed as an economic driver (Goldsmith, 2013), in many states a portion of funding allocations is no longer based on institutional needs, but on how well institutions are meeting state objectives toward economic development.

How to finance higher education remains controversial among policy makers and constituencies across the United States (Rabovsky, 2014). Texas is not exempt from the controversy. With increasingly strained state finances, institutions of higher education and the Texas Higher Education Coordinating Board (THECB) have come under pressure to increase performance accountability, efficiency, and competitiveness. In Texas, House Bill 9 (H.B. 9) was enacted in 2011 to dedicate a portion of state funding to public colleges and universities that meet specific performance-based standards. Although H.B. 9 has been passed and signed into law, it still has not been determined how funding will be distributed or how effective it will be. This paper analyzes data from several states with similar performance-based funding standards to help bring to light to the possible effects H.B. 9 will have on Texas' public four-year universities.

\section{Background}

The value of a college education is in high demand and the success of students has crucial implications both socially and economically. Many states require more accountability for higher education accountability and it has been growing nationally over the past three decades (McLendon \& Hearn, 2013). An array of public reports, journal articles, and books has fueled the emergence of the accountability and performance movements in higher education (e.g., Description of State Performance Funding Programs, 2013; Hillman, Tandberg, \& Gross, 2014; McKeown-Moak, 2013; Washington Higher Education Coordinating Board, 2011). According to Bogue (2010), there is a national concern for better accountability policies to govern higher education performance. The National Center for Public Policy in Higher Education graded state higher education systems on factors such as preparation, participation, completion, affordability and learning outcomes (Bogue, 2010). These concerns have influenced Texas legislators. Over the years, the primary policy question for legislators in Texas was how to allocate state appropriations equitably among a growing and diverse number of public colleges and universities (THECB, 2011). State legislators sought to address that question by implementing performance-based funding, similar to other states. 
The transition to a global economy has increased the value on human capital for individual and collective economic security. Recognizing this, President Obama set the national goal of leading the world in the proportion of college graduates by 2020 (Harnisch, 2011). Boosting graduation rates in an austere funding environment has led to a national productivity agenda for higher education. The policy issue that arose in Texas, then, is that H.B. 9 is the shift to performance-based funding efforts aimed at offering more high-quality college opportunities to a greater number of students within existing budgetary constraints. According to Lederman (2011), performance-based funding is a favored tool of policy makers as they push higher education toward greater efficiency and better outcomes in terms of college retention and completion. Policy makers argue that if states can change the incentives for colleges and universities by funding them for retaining and graduating students, institutions alter their behavior (Lederman, 2011).

\section{Problem Statement}

Understanding the diverse nature of performance-based funding environments will provide a useful landscape to better analyze a variety of outcomes. To build a useful, inclusive, and effective performance-based funding model, meaningful data will be needed before decision makers can identify best practices and develop a strong, flexible and equitable framework.

According to the National Conference of State Legislatures (2014), twenty-four states currently have some form of performance funding for higher education. Originally, Texas was ahead of the curve when it began discussing the idea but other states leapt ahead and now Texas is in the middle of the pack (The Texas Tribune, 2014). For the past three legislative sessions, coordinating board leaders in Texas were working to implement a shift in funding to universities from formula funding focused on enrollments to formula funding that creates incentives for institutions to raise student achievements. Currently at the coordinating board, an advisory group consisting of university representatives is continuing to make modifications so that performance-based funding will benefit all public universities and not just a select few (THECB, 2014).

Many representatives from institutions of higher education remain skeptical of performance-based funding. They question whether or not allocations under such policies adequately reflect the major differences in institutional missions and the diversity of students served, or whether such policies exacerbate inequalities in institutional funding (AAUP, 2014). In addition, a new round of research shows that performance-based funding programs do not work; at least to the extent states are trying to increase degree completion. One such study by Florida State University examined performance-based systems in 19 states and found that while those programs were largely designed to increase the number of students completing degrees, it did so only in four of them. In six states completions actually declined and the results were inconclusive in nine other states (Lederman, 2014). Advocates for performance-based funding argue that effectiveness will grow as state appropriations linked to them does (Rabovsky, 2014). They also argue it is too early to gauge the success of the most recently enacted performance funding systems which tend to have higher stakes, as is the case in the state of Texas. Concerns raised by leaders in Texas higher education do not 
believe that the new performance-based funding model is strong enough yet to dictate more than $10 \%$ of university funding and many are asking what research is available for them to better understand the effect performance funding will have on Texas (Lederman, 2014). According to a study conducted by Columbia University in 2012, it is rare to find studies that sample across different kinds of institutions, such as flagship state universities and their system regional schools. There are 38 public four-year universities in Texas that range in size and cater to varying populations with different goals. Because performance-based funding model in Texas continues to be developed, there is insufficient data for the task of making funding distinctions. The purpose of this paper assesses performance-based standards as they apply to public, four-year institutions with similarities with Texas. Data include performance-based standards, state higher education appropriations to higher education, percentage and funding allocations according performance-based standards, ratios of appropriations funding to performance-based funding, and Texas' institutions' operating budgets and state appropriations per institution (Two-year institutions are not included since they have different performance standards and metrics).

\section{Funding Analysis}

Texas is yet to fully implement performance-based funding. However, as it works to build a framework for the emergence of performance-based funding, it is important to examine the financial distribution of other states that have implemented performance-based models similar to those stipulated by H.B. 9 (See Appendix B). In Texas, legislation redirected 10\% of the state's enrollment driven funding for allocation to universities based on specific standards, such as total undergraduate degrees, time to degree, institutional mission factor, cost-to-degree, critical fields factor (Science, Technology, Engineering, and Mathematics-STEM and STEM related), at-risk factor and six-year graduation rates (THECB, 2011). Twenty-four other states have formula funding in place that allocates some amount of funding based on performance standards, such as course completion, time to degree, transfer rates, the number of degrees awarded and the number of low-income and minority graduates (NCSL, 2014).

The table in Appendix A outlines data related to the states that have implemented performance-based funding. It conveys their individual distribution and the year in which performance-based funding was instituted. The most common performance metric across the board can be identified as the number of degrees awarded, 19 out of 24 states, including Texas; have linked undergraduate graduation rates with funding allocations. Degrees with STEM credentials, otherwise known as critical field degrees, are the second most common metric. Thirteen of 24 states including Texas allocate funding for STEM degrees.

The table in Appendix B outlines the distribution of state based allocated funds by percentage for each metric (see Appendix G for items of performance-based standards). The table includes the 15 states where four-year universities have standards similar to those designated by the Texas legislature in H.B. 9. The range varies from as low as .06\% state allocation for all standards in Michigan to $100 \%$ state allocation designated to total hours completed in North Dakota. State based allocation designated to the number of degrees awarded ranges 
from $.06 \%$ in Michigan to $50 \%$ in Ohio. The number of degrees awarded is the most common metric used in performance funding models yet it only constitutes the second largest percentage of funding recovery with an average weighted metric of $22 \%$. Science, Technology, Engineering, and Mathematics degrees are the second most common metric and are weighted third highest with an average weight of $19 \%$. Total credit hours completed is the largest weight overall at $41 \%$.

The table in Appendix C outlines the 2013-2014 percentages of state appropriations to higher education, as well as the 2013-2014 percentage of state allocation to performance-based funding. In addition, the total performance-based allocation for each state is provided. Tennessee and Ohio are the only two states to have $100 \%$ performance-based funding formulas in place. In 2014, Texas had the highest state allocation of funding to higher education totaling $\$ 6.6$ billion followed by Illinois totaling $\$ 4$ billion. In 2014 , Ohio had the highest allocation to performance-based funding totaling $\$ 1.1$ billion followed by Minnesota totaling \$52 million. Data sets for both 2014 state appropriations and allocations to performance-based funding are provided by the Lumina Foundation and the National Conference of State Legislatures.

The table in Appendix D converts percentages into dollar amounts attributing a funding designation. For example, in 2014 Arkansas allocated \$852 million for funding its four-year institutions. Of that amount, the state allocated approximately $\$ 42$ million to be distributed among all five performance-based standards. According to Appendix C, 5\% will be allocated to total credit hours/course completion, which results in $\$ 2.1$ million as seen on Appendix D. According to the distributions among all the states and categories presented in this paper, the table reveals where states place priority based on the amount of dollars they choose to allocate toward performance-based funding for four-year institutions. Two-year institutions are not included since they have different performance standards and metrics. As a reminder, only those states that have performance-based standards similar to Texas are included. The data below gives an indication of how performance-based funding according to standards could be distributed if all state, four-year institutions performed equally. For example, Arkansas has 11 four-year institutions. This means 11 institutions must compete for a portion of the \$2.1 million for the performance-based funding allocated to the total credit hours/course completion standard. Since the allocation is based on performance, not all institutions will receive the same amount. However, if it is assumed that each institution would receive the same amount, they would receive only $\$ 191,000$ each $(\$ 2.1$ million/11 institutions). The information below in Table 1 shows the number of four-year institutions per state that would have to compete for performance-based funding for their respective criteria (Texas excluded since no financial data are available). 
Table 1. Four year institutions per state

\begin{tabular}{|c|c|c|c|c|c|c|c|c|c|c|c|c|c|c|}
\hline & \#4YRs & $* 1$ & $* 2$ & $* 3$ & $* 4$ & $* 5$ & $* 6$ & $* 7$ & $* 8$ & $* 9$ & $* 10$ & $* 11$ & $* 12$ & $* 13$ \\
\hline $\mathrm{AK}$ & 11 & $2.1 \mathrm{M}$ & & & $4.2 \mathrm{M}$ & $10.5 \mathrm{M}$ & $8.4 \mathrm{M}$ & $6.3 \mathrm{M}$ & & & & & & \\
\hline FL & 12 & & $5 \mathrm{M}$ & & $6 \mathrm{M}$ & & $3 \mathrm{M}$ & $2 \mathrm{M}$ & & & $2 \mathrm{M}$ & & & \\
\hline IL & 13 & $2.4 \mathrm{M}$ & & & $2.4 \mathrm{M}$ & $2.4 \mathrm{M}$ & $2.4 \mathrm{M}$ & $2.4 \mathrm{M}$ & & & & & & \\
\hline IN & 15 & & $27.45 \mathrm{M}$ & & $18.3 \mathrm{M}$ & & $9.15 \mathrm{M}$ & $6.1 \mathrm{M}$ & & & & & & \\
\hline MI & 15 & & & & $14.4 \mathrm{~K}$ & & & $14.4 \mathrm{~K}$ & $14.4 \mathrm{~K}$ & & & & & \\
\hline $\mathrm{MN}$ & 12 & & & & $10.4 \mathrm{M}$ & & $10.4 \mathrm{M}$ & $10.4 \mathrm{M}$ & & $10.4 \mathrm{M}$ & & & & $10.4 \mathrm{M}$ \\
\hline MS & 8 & $27.9 \mathrm{M}$ & $620 \mathrm{~K}$ & & $620 \mathrm{~K}$ & & $620 \mathrm{~K}$ & & $620 \mathrm{~K}$ & & & $620 \mathrm{~K}$ & & \\
\hline MO & 13 & $5 \mathrm{M}$ & $5 \mathrm{M}$ & & $5 \mathrm{M}$ & & & & $5 \mathrm{M}$ & & & $5 \mathrm{M}$ & & \\
\hline NM & 6 & $11.5 \mathrm{M}$ & & & $3.63 \mathrm{M}$ & & $4.95 \mathrm{M}$ & $3.63 \mathrm{M}$ & & $660 \mathrm{~K}$ & & & & \\
\hline NV & 6 & & $1.9 \mathrm{M}$ & $950 \mathrm{~K}$ & $7.6 \mathrm{M}$ & & $2.85 \mathrm{M}$ & $2.85 \mathrm{M}$ & $1.9 \mathrm{M}$ & & & & & \\
\hline ND & 6 & $5 \mathrm{M}$ & & & & & & & & & & & & \\
\hline $\mathrm{OH}$ & 38 & $330 \mathrm{M}$ & & & $550 \mathrm{M}$ & & & *bonus & & & & & & \\
\hline SD & 6 & & & & & & & $3 \mathrm{M}$ & $3 \mathrm{M}$ & & & & & \\
\hline $\mathrm{TN}$ & 11 & $900 \mathrm{~K}$ & $1.2 \mathrm{M}$ & $600 \mathrm{~K}$ & $1.5 \mathrm{M}$ & & & & $600 \mathrm{~K}$ & & & & & \\
\hline TX & 38 & $\mathrm{X}$ & $X$ & & $\mathrm{X}$ & $X$ & $X$ & $\mathrm{X}$ & & & & & & \\
\hline
\end{tabular}

Note. $1=$ Total credit hrs/course completion; $2=$ Time to degree; $3=$ Transfer rates; $4=\#$ of degrees awarded; $5=$ Minority students; $6=\#$ low income $/ 1^{\text {st }}$ generation graduates $/$ at risk; 7 $=$ STEM credentials; $8=$ External research $\$ ; 9=$ Graduates employed or continuing; $10=\#$ of degrees focused on state strategic plan; $11=$ Cost per completion; $12=$ Remedial courses; $13=$ Retention rates.

The table in Appendix E outlines two types of ratios. First, it shows the ratio of how much a state allocates from its total funding appropriations for each performance-based standard. For example, in 2014 Arkansas appropriated $\$ 852$ for all its four-year institutions. For every $\$ 406$ million spent on four-year higher education, $\$ 1$ million is allocated to the total credit hours/course completion criterion. It has to be remembered that the standard is capped at $\$ 2.1$ million and has to be shared among 11 of institutions. Second, the information shows the ratio of actual funding dedicated to each standard. Since there is only $\$ 42$ million dedicated to performance-based funding in Arkansas, the ratio is 20:1. Thus, for every $\$ 20$ million allocated to performance-based funding, $\$ 1$ million is dedicated to total credit hours/course 
completion. Again, the standard is capped at \$2.1 million and has to be shared among 11 institutions.

As the data are further categorized, a trend begins to emerge. It appears that very little funding is provided for performance-based funding (It is more evident when Appendix $\mathrm{F}$ is discussed). This becomes particularly apparent when the funding is examined according to three tendencies. First, the total amount of funding for performance-based standards is very little when compared to states' total appropriations. Second, the performance-based amount has to be spread among a number of standards. Third, each institution in each state has to compete for the amount allocated per each standard, which further dilutes the amount an institution might receive. This leads to a major concern. With regard to institutions' operating budgets and state appropriations, the analysis portrays a dire perspective for individual institutions to compete for performance-based funding.

The table in Appendix F lists three major state university system institutions in Texas to include the University of Texas at Austin (flagship), Texas A\&M University at College Station (flagship), and the University of Houston (flagship). The 2014 operating budget of Texas A\&M University at College Station is over \$1 billion more than the second largest school in the system, Texas A\&M University-Corpus Christi and over \$200 million more in state appropriations. Likewise, the operating budget of the University of Texas at Austin is $\$ 1.2$ billion more than the second largest school in the system, The University of Texas at Arlington and over $\$ 52$ million more in state appropriations. It suggests that larger institutions have the resources, financial and human capital, to respond to state mandates better than regional institutions.

Although financial data do not exist yet for Texas based on performance-based allocations, the trend could very well be similar to other states. For most states the majority of funding comes from state allocations other than performance-based formulas. However, institutions have to divert resources from current needs toward compliance with state mandates for performance-based standards (Sanford \& Hunter, 2011) with little to show in return (Sanford \& Hunter, 2011; Shin, 2010; Volkwein \& Tandberg, 2008). “[R]ecent studies have concluded that performance-funding-oriented reforms have had negligible impacts on organizational performance and student outcomes" (Rabovsky, 2014: p. 763).

Possibly, of greater concern is actual distribution of funds. Performance-based standards will tend to favor some institutions over others. For example, institutions with strong STEM programs have an advantage over others according to the STEM standard. This also applies to other performance-based standards, such as number of minority students served; external research funding; and number of low income and first generation or at-risk students. Some institutions are positioned better for achieving these outcomes than others according to resources, mission, and/or geographical location. Therefore, some institutions stand to lose or not receive performance-based funding simply because of the misfortune of their existence in a particular region.

Tennessee and Ohio are two exceptions and are good examples of institutions who implemented performance-based funding early enough to have perfected models that 
overcome challenges regarding design and implementation, institutional autonomy, student body disparities and contrasting regional university missions.

\section{Conclusions}

The funding environment for higher education in many states has radically changed. Performance-based funding, if it has been implemented, varies according to standards, funding amounts, and percentages of allocations. In an effort to help bring to light the possible effects of performance-based funding will have on Texas' public four-year universities, this paper looked at common criteria among 14 states and the funding allocated to them. Policymakers across the country are working towards connecting performance with funding and assigning dollar amounts to metrics in a competitive environment. In an attempt to solve some state problems a competitive environment grounded in performance-based funding could cause problems among the 38 public four-year universities in Texas.

The creation of university systems in Texas were a result of rapid growth to higher education in Texas. Where there is growth, there is a need for governance to deal with the complex issues of governance. The structures of system institutions include that of a flagship institution and regional campuses spread throughout the state. Concerns of how the growth of regional institutions negatively impact flagship campuses is still a conversation ongoing in most system institutions as regional institutions are seen as a drain of resources and funding away from the flagship (McLendon \& Hearn, 2013). The latest proposal for performance-based funding was recently drafted by a committee representing institutions across Texas tasked by the legislature with developing a one size fits all model. A one size fits all model is doubtful, though. Several regional institutions that rely on part-time and low-income students often have some of the lowest graduation rates and time to degree in the state. They fear the model is not nearly flexible enough for them to benefit from state mandates (Wermund, 2014). Additionally, flagship universities in Texas may already possess the resources to respond to legislative mandates, whereas smaller, regional institutions could struggle with reallocation of resources, academic and support program development, and access to human capital in order to meet state mandates.

There are no solid data results yet available for Texas for its performance-based initiatives. Nevertheless, it is still possible to understand some general effects that performance-based funding may have on the 38 public four-year institutions by converting weights into dollar amounts designed for individual standard. In 2014 Texas allocated $\$ 6.6$ billion to higher education. Of that amount, Texas plans to allocate 10\% (\$660 million) to performance-based funding. The allocations are weighted so no percentages have been established. However, five criteria are weighted as 1 and three are weighted as 2 . If 1 is converted to percentages at $9 \%$, then 2 would be approximately $18 \%$. This would represent approximately $100 \%$ of the $\$ 660$ million for performance-based allocations. Assuming the distributions are equal among the institutions, that is, they all performed equally well according to the standards, the allocations would be as follows. 
> Allocations to Completion Rates: \$59.4 million (1 weighted);

$>$ Time to Degree: $\$ 59.4$ million (1 weighted);

$>$ Transfer Rates: \$59.4 million (1 weighted);

$>\quad$ Number of Degrees Awarded: \$59.4 million (1 weighted);

> Minority Students: $\$ 118.8$ million (2 weighted);

$>\quad$ Number of Low Income/First Generation, At-Risk Students \$118.8 million;

> STEM Credentials: $\$ 118.8$ million(2 weighted);

$>$ External Research Funding: \$59.4 (1 weighted).

Again, assuming all 38 public four-year institutions performed equally, they would each receive $\$ 1.56$ million for each 1 weighted criteria and $\$ 3.13$ for each 2 weighted criteria.

There are two caveats to this, though. First, the state has not yet determined if this funding will be in addition to regular appropriations or as part of them. If it is in addition to regular appropriations, it is a bonus. If not, it could be a detriment. Second, a distribution of $\$ 1.56$ million dollars for 1 weighted standard to each institution assumes each one performed similarly with respect to the standard. This is too much to assume since all institutions will not perform similarly. Furthermore, if performance-based funding is part of regular allocations, institutions could stand to lose millions, again simply because of the misfortune of their existence in a particular region and according to their mission. As a side note, it could force institutions toward budget cuts. Administrators may choose to reduce their budgets by the amount of performance-based funding available since there is no guarantee their institution will receive it.

Another effect of performance-based funding is homogeneity of education. The state could very well have unintended consequences of homogeneity. Although a $10 \%$ allocation of state funding for performance appears minimal, for smaller institutions it represents a larger proportion of their operating budget (See Appendix F). It may force smaller, regional institutions to develop academic and support programs that other institutions already have. Instead of promoting diversity, Texas could see a shift toward homogeneity of programs, services, and outcomes. This is particularly troublesome for institutions, since they cannot control who decides to attend college. The December 2014 Texas State Higher Education Committee Interim Report reflected this problem. For example: "The growth in participation rates has been uneven among racial/ethnic groups in Texas; there is a growing gender gap in Texas higher education" (p. 7). It will be difficult for institutions to achieve the minority student performance-based criteria when state minority participation wanes and is different in various regions.

It appears that if performance-based funding will be effective, it should consider at least two factors. First, allocations should be in addition to regular funding. It would give a sense of incentives instead of punishments since it would be in addition to regular appropriations instead of penalizing institutions by withholding appropriations. Second, allocations must be 
based on proportionate matrices. For example, performance-based funding for minority student enrollment could be allocated according to the proportion of minority eligible students in the region that a university serves. A university student body should be proportionate in minority student enrollments in line with the region it serves. This approach would address the two caveats listed above, as well as address the diversity of the state.

A proportional approach to allocations would apply to other standards. Regional institutions cannot compete for research funding in the same vein as flagship institutions. For example, distribution of funds linked to external research dollars provides significant challenges at the regional level. "On a practical note, US\$35 million to US\$405 million annually from grants and contracts are awarded to the top 88 research universities [in the nation] with a mean of \$US130 million" (Bowden \& Gonzalez, 2012, p. 16). With a pool of research funding already spread thin, it makes competition for performance-based funding according to the external research standard extremely difficult for regional institutions. However, if a formula grounded in a proportional matrix were developed and implemented, it could help provide incentives for research at smaller institutions, as well as provide an environment of fair competition. This is an oversimplification of a solution, though. A proportional funding formula could over reward some institutions according to current institutions' operating budgets and state appropriations. Would it be fair for the regional institution, University of Texas-Tyler, to receive $\$ 3.13$ million of performance-based funding with an operating budget of $\$ 51.9$ million and the flagship institution, University of Texas-Austin, to receive $\$ 3.13$ million with an operating budget of $\$ 1.61$ billion? It is not just the allocation of funds that is a problem.

The cost to ramp up research to the level of meeting the proposed standard for external research in H. B. 9 is significant, not to mention a very slow process. Flagship universities are already operating at a high level of research and sponsored projects. It will be imperative to consider the effects of this standard on the multitude of smaller regional campuses that are not positioned to meet this requirement for funding. Not only do they not have the resources to compete for research dollars, their mission may not be consistent with the standard. Other performance-based standards have hurdles to overcome as well. For instance, is there a greater financial cost to larger institutions than smaller ones to design, implement, and operate programs related to completion rates? The data are just not yet available to address many of the concerns, issues, and problems being raised. In the short term, the initial analysis does not appear promising. However, larger institutions and those regionally positioned, which are congruent with the performance-based standards may fair very well. Analysts and researchers need more time and more data. Unfortunately, it may come too late for some state four-year institutions.

\section{Summary}

As Texas closes in on state-wide implementation of performance-based standards and as newly elected officials enter the higher education policy arena, it is more important than ever to understand how regional institutions can best position themselves. There is no proven strategy to ensure the universal success of performance funding models; therefore differences 
in institutional capacity seem to be an obstacle to effective performance-based funding implementation. Faced with uncertainties regarding equitable performance-based funding in Texas, decision makers could consider separating funding formulas to accommodate various regional institutions within a university system with varying research goals and missions. Likewise, more information is needed on the cost to institutions of meeting state demands for performance-based funding data, developing effective organizational learning capacity, mounting initiatives to improve institutional performance, and evaluating the results of those initiatives. Better estimates are needed to determine whether the fiscal benefits of performance-based funding outweighs the costs to institutions and therefore whether states need to make to concerted efforts to offset those costs if they wish performance funding to be welcomed by colleges (Dougherty \& Reddy, 2011).

Conversations on performance-based funding are advancing as state economies tighten, budgets are reduced, and the national push for market-driven reforms to higher education gain popularity. It is clear performance-based funding impacts colleges and universities by increased understanding of state priorities, competition among institutions, and greater institutional awareness. Performance-based funding was implemented, in part, to level the playing field in formula funding, as well as provide equity in rewards. However, if current trends continue, it is likely that accountability will increase as will costs, but efficiency will decrease particularly for the smaller system regional institutions that are spending money in the fight for funding.

\section{References}

Bogue, E. G., \& Hall, K. B. (2010). Quality and accountability in higher education: Improving policy, enhancing performance. Westport, Conn: Praeger.

Bowden, R., \& Gonzalez, L. (2012). The rise of contingent faculty: Its implications on the professoriate and higher education. Journal of Applied Research in Higher Education, 4(1), 5-22. http://dx.doi.org/10.1108/17581181211230603

Center for American Progress. (August, 2012). Retrieved from http://www.centerforamericanprogress.com

Cohen, A. M., \& Kisker, C. B. (2010). The shaping of American higher education: Emergence and growth of the contemporary system. San Francisco, CA: Jossey-Bass.

Description of State Performance Funding Programs. (2013). ASHE Higher Education Report, 39(2), 17-34.

Dougherty, K., \& Reddy, V. (2011). The impacts of state performance funding systems on higher education institutions: Research literature and policy recommendations. New York, NY: Columbia University.

Goldsmith, G. C. (2013). Higher education: Economic benefits and an examination of access and completion gaps. New York : Nova Publishers.

Harnish, T. (2011). Higher education policy brief. American Association of State Colleges 
and Universities. Retrieved from http://www.aascu.org

Hillman, N. W., Tandberg, D. A., \& Gross, J. P. K. (2014). Performance funding in higher education: Do financial incentives impact college completions? The Journal of Higher Education, 85(6), 826-857. http://dx.doi.org/10.1353/jhe.2014.0031

Lederman, D. (2014). Performance funding underperforms. Retrieved from http://www.insidehighered.com

Lumina Foundation. (December, 2014). Retrieved from http://strategylabs.luminafoundation. org/wp-content/uploads/2013/03/OBF_Notes.pdf

McKeown-Moak, M. P. (2013). The "new" performance funding in higher education. Educational Considerations, 40(2), 3-12. Retrieved from http://eds.a.ebscohost.com

McLendon, M. K., \&Hearn, J. C. (2013). The resurgent interest in performance-based funding for higher education. Academe, 99(6), 25-30. Retrieved from http://eds.a.ebscohost.com

Miao, K. (2012). Performance-based funding of higher education: A detailed look at best practices in 6 States. Center for American Progress. Retrieved from https://www.americanprogress.org/issues/higher-education/report/2012/08/07/12036/perform ance-based-funding-of-higher-education/

National Conference of State Legislatures. (November, 2014). Retrieved from http://www.NSCL.com

Rabovsky, T. (2014). Support for performance-based funding: The role of political ideology, performance, and dysfunctional information environments. Public Administration Review, 74(6), 761-774. http://dx.doi.org/10.1111/puar.12274

Sanford, T., \& Hunter, J. M. (2011). Impact of performance-funding on retention and graduation rates. Education Policy Analysis Archives, 19(33), 1-30. Retrieved from http://dx.doi.org/10.14507/epaa.v19n33.2011

Senate Higher Education Committee Interim Report. (December 2014). The State of Texas. Austin, TX. Retrieved from http://www.senate.state.tx.us/75r/senate/commit/c560/c560.htm

Shin, J.-C. (2010). Impacts of performance-based accountability on institutional performance in the U.S. Higher Education, 60(1), 47-6. http://dx.doi.org/10.1007/s10734-009-9285-y

Volkwein, J. F., \& Tandberg, D. (2008). Measuring up: Examining the connections among state structural characteristics, regulatory practices, and performance. Research in higher Education, 49(2), 180-9. http://dx.doi.org/10.1007/s11162-007-9066-3

Washington Higher Education Coordinating Board. (2011). Performance-based funding brief. Washington Higher Education Coordinating Board. Retrieved from http://eds.a.ebscohost.com 


\section{Macrothink}

\section{Appendix}

Appendix A. University Metrics Aligned with Texas

\begin{tabular}{|c|c|c|c|c|c|c|c|c|c|c|c|c|c|c|c|c|c|c|c|c|c|c|c|c|}
\hline & $\mathrm{AZ}$ & AK & $\mathrm{FL}$ & IL & IN & KS & LA & $\mathrm{ME}$ & MI & MN & MS & MO & NM & NV & $\mathrm{NC}$ & ND & $\mathrm{OH}$ & OK & PA & SD & $\mathrm{TN}$ & $\mathbf{T X}$ & UT & WA \\
\hline PFB implemented & '13 & ' 14 & '13 & '11 & ‘11 & ‘ 11 & '10 & '13 & ' 12 & '14 & '12 & '14 & ‘ 12 & $‘ 11$ & '13 & ‘11 & ' 10 & ‘08 & '00 & ' 13 & ‘ 10 & ‘11 & 2013 & 2007 \\
\hline \multicolumn{25}{|l|}{ Bachelor Credits Hrs } \\
\hline Total Credit Hrs & & $\mathrm{X}$ & & $\mathrm{X}$ & & & & & & & $\mathrm{X}$ & & $\mathrm{X}$ & & & $\mathrm{X}$ & $\mathrm{X}$ & $\mathrm{X}$ & & & $\mathrm{X}$ & $\mathbf{x}$ & & $\mathrm{X}$ \\
\hline Time to Degree & & $\mathrm{X}$ & $\mathrm{X}$ & & $\mathrm{X}$ & & & & $\mathrm{X}$ & & & $\mathrm{X}$ & & & $\mathrm{X}$ & & & & & & $\mathrm{X}$ & $\mathbf{x}$ & & \\
\hline Transfer Rates & & & $\mathrm{X}$ & & & & $\mathrm{X}$ & & $\mathrm{X}$ & & & & & $\mathrm{X}$ & $\mathrm{X}$ & & & & & & $\mathrm{X}$ & $\mathbf{x}$ & & $\mathrm{X}$ \\
\hline Degrees Awarded & $\mathrm{X}$ & & & $\mathrm{X}$ & $\mathrm{X}$ & $\mathrm{X}$ & $\mathrm{X}$ & $\mathrm{X}$ & $\mathrm{X}$ & $\mathrm{X}$ & $\mathrm{X}$ & $\mathrm{X}$ & $\mathrm{X}$ & $\mathrm{X}$ & $\mathrm{X}$ & & $\mathrm{X}$ & $\mathrm{X}$ & & & $\mathrm{X}$ & $\mathbf{X}$ & $\mathrm{X}$ & $\mathrm{X}$ \\
\hline & & $\mathrm{X}$ & $\mathrm{X}$ & & $\mathrm{X}$ & & & & & $\mathrm{X}$ & $\mathrm{X}$ & $\mathrm{X}$ & & & & & $\mathrm{X}$ & & $\mathrm{X}$ & & & & & $\mathrm{X}$ \\
\hline STEM Credentials & & $\mathrm{X}$ & & $\mathrm{X}$ & $\mathrm{X}$ & $\mathrm{X}$ & & $\mathrm{X}$ & $\mathrm{X}$ & $\mathrm{X}$ & $\mathrm{X}$ & & & $\mathrm{X}$ & $\mathrm{X}$ & & & & $\mathrm{X}$ & $\mathrm{X}$ & & $\mathbf{X}$ & & \\
\hline External Research \$ & & & & $\mathrm{X}$ & & & $\mathrm{X}$ & $\mathrm{X}$ & $\mathrm{X}$ & & $\mathrm{X}$ & & $\mathrm{X}$ & $\mathrm{X}$ & & & & & $\mathrm{X}$ & $\mathrm{X}$ & $\mathrm{X}$ & $\mathbf{X}$ & & \\
\hline $\begin{array}{l}\text { Graduates employed } \\
\text { or continuing }\end{array}$ & & & $\mathrm{X}$ & & & $\mathrm{X}$ & $\mathrm{X}$ & & & $\mathrm{X}$ & & $\mathrm{X}$ & & $\mathrm{X}$ & & & & & & & & & & \\
\hline Degrees focused on & & & $\mathrm{X}$ & & & $\mathrm{X}$ & $\mathrm{X}$ & & & & & & & $\mathrm{X}$ & & & & & $\mathrm{X}$ & & & & & \\
\hline Cost per completion & & & $\mathrm{X}$ & $\mathrm{X}$ & & & & $\mathrm{X}$ & $\mathrm{X}$ & & $\mathrm{X}$ & $\mathrm{X}$ & & & & & & & & & & & & \\
\hline Remedial courses & & & & & $\mathrm{X}$ & & & & & & & & & & $\mathrm{X}$ & & $\mathrm{X}$ & & & & & $\mathbf{X}$ & $\mathrm{X}$ & $\mathrm{X}$ \\
\hline Retention rates & & & & & & $\mathrm{X}$ & $\mathrm{X}$ & & & $\mathrm{X}$ & & $\mathrm{X}$ & & & & & & $\mathrm{X}$ & & & & & $\mathrm{X}$ & \\
\hline
\end{tabular}


Appendix B. State Base Allocation for PBF

\begin{tabular}{|c|c|c|c|c|c|c|c|c|c|c|c|c|c|c|c|}
\hline & $\mathrm{AK}$ & FL & IL & IN & MI & $\mathrm{MN}$ & MS & MO & NM & NV & ND & $\mathrm{OH}$ & SD & $\mathrm{TN}$ & $\mathbf{T X}$ \\
\hline $\begin{array}{l}\text { Total Credit Hrs/ } \\
\text { Course Completion }\end{array}$ & $10 \%$ & & $40 \%$ & & & & $90 \%$ & $20 \%$ & $35 \%$ & & $90 \%$ & $30 \%$ & & $15 \%$ & 1 \\
\hline Time to Degree & & $25 \%$ & & $45 \%$ & & & $2 \%$ & $20 \%$ & & $10 \%$ & & & & $20 \%$ & 1 \\
\hline Transfer Rates & & & & & & & & & & $5 \%$ & & & & $10 \%$ & 1 \\
\hline Degrees Awarded & $10 \%$ & $30 \%$ & & $30 \%$ & $0.06 \%$ & $20 \%$ & $2 \%$ & $20 \%$ & $11 \%$ & $40 \%$ & & $50 \%$ & & $25 \%$ & 1 \\
\hline Minority Students & $25 \%$ & & $40 \%$ & & & & & & & & & & & & 2 \\
\hline Low-Income "at risk" & $20 \%$ & $15 \%$ & $40 \%$ & $15 \%$ & & $20 \%$ & $2 \%$ & & $15 \%$ & $15 \%$ & & & & & 2 \\
\hline STEM Credentials & $15 \%$ & $10 \%$ & $40 \%$ & $10 \%$ & $0.06 \%$ & $20 \%$ & & & $11 \%$ & $15 \%$ & & *bonus & $50 \%$ & & 2 \\
\hline External Research \$ & & & & & $0.06 \%$ & & $2 \%$ & $20 \%$ & & $10 \%$ & & & $50 \%$ & $10 \%$ & 1 \\
\hline $\begin{array}{l}\text { Graduates employed or } \\
\text { continuing education }\end{array}$ & & & & & & $20 \%$ & & & $2 \%$ & & & & & & \\
\hline $\begin{array}{l}\text { Degrees focused on } \\
\text { State strategic plan }\end{array}$ & & $10 \%$ & & & & & & & & & & & & & \\
\hline Cost per completion & & & & & & & $2 \%$ & $20 \%$ & & & & & & & \\
\hline Remedial courses & & $10 \%$ & & & & & & & & & & & & & \\
\hline Retention rates & & & & & & $20 \%$ & & & & & & & & & \\
\hline State Allocated Base & $10 \%$ & $6 \%$ & $1 \%$ & $6 \%$ & $2.00 \%$ & $5 \%$ & $15 \%$ & $10 \%$ & $5 \%$ & $5 \%$ & $90 \%$ & $100 \%$ & $10 \%$ & $100 \%$ & $10 \%$ \\
\hline
\end{tabular}


Appendix C. State/PBF Allocation by Percentage

\begin{tabular}{|c|c|c|c|c|c|c|c|c|c|c|c|c|c|c|c|}
\hline & $\mathrm{AK}$ & FL & $\mathrm{IL}$ & IN & MI & MN & MS & MO & NM & NV & ND & $\mathrm{OH}$ & SD & $\mathrm{TN}$ & TX \\
\hline $\begin{array}{l}\text { Total Credit Hrs/ } \\
\text { Course Completion }\end{array}$ & $5 \%$ & & $40 \%$ & & & & $90 \%$ & $20 \%$ & $35 \%$ & & $100 \%$ & $30 \%$ & & $15 \%$ & 1 \\
\hline Time to Degree & & $25 \%$ & & $45 \%$ & & & $2 \%$ & $20 \%$ & & $10 \%$ & & & & $20 \%$ & 1 \\
\hline Transfer Rates & & & & & & & & & & $5 \%$ & & & & $10 \%$ & 1 \\
\hline Degrees Awarded & $10 \%$ & $30 \%$ & $40 \%$ & $30 \%$ & $0.06 \%$ & $20 \%$ & $2 \%$ & $20 \%$ & $11 \%$ & $40 \%$ & & $50 \%$ & & $25 \%$ & 1 \\
\hline Minority Students & $25 \%$ & & $40 \%$ & & & & & & & $5 \%$ & & & & & 2 \\
\hline Low-Income "at risk" & $20 \%$ & $15 \%$ & $40 \%$ & $15 \%$ & & $20 \%$ & $2 \%$ & & $15 \%$ & $5 \%$ & & & & & 2 \\
\hline STEM Credentials & $15 \%$ & $10 \%$ & $40 \%$ & $10 \%$ & $0.06 \%$ & $20 \%$ & & & $11 \%$ & $15 \%$ & & *bonus & $50 \%$ & & 2 \\
\hline External Research \$ & & & & & $0.06 \%$ & & $2 \%$ & $20 \%$ & & $10 \%$ & & & $50 \%$ & $10 \%$ & 1 \\
\hline $\begin{array}{l}\text { Graduates employed or } \\
\text { continuing education }\end{array}$ & & & & & & $20 \%$ & & & $2 \%$ & $10 \%$ & & & & & \\
\hline $\begin{array}{l}\text { Degrees focused on } \\
\text { State strategic plan }\end{array}$ & & $10 \%$ & & & & & & & & & & & & & \\
\hline Cost per completion & & & & & & & $2 \%$ & $20 \%$ & & & & & & & \\
\hline Retention rates & & & & & & $20 \%$ & & & & & & & & & \\
\hline Current PBF Allocation & $10 \%$ & $6 \%$ & $<1 \%$ & $6 \%$ & $2 \%$ & $5 \%$ & $15 \%$ & $10 \%$ & $5 \%$ & $5 \%$ & $90 \%$ & $100 \%$ & $10 \%$ & $100 \%$ & $10 \%$ \\
\hline 2014 State HE allocation & $852 \mathrm{M}$ & $3.9 \mathrm{~B}$ & $4 \mathrm{~B}$ & $1.7 \mathrm{~B}$ & $1.7 \mathrm{~B}$ & $1.4 \mathrm{~B}$ & $973 \mathrm{M}$ & $967 \mathrm{M}$ & $871 \mathrm{M}$ & $487 \mathrm{M}$ & $409 \mathrm{M}$ & $2.1 \mathrm{~B}$ & $198 \mathrm{M}$ & 1.6B & $6.6 \mathrm{~B}$ \\
\hline 2014 allocation to PBF & $40 \mathrm{M}$ & $200 \mathrm{M}$ & $5.9 \mathrm{M}$ & $46 \mathrm{M}$ & $38 \mathrm{M}$ & $52 \mathrm{M}$ & $31 \mathrm{M}$ & $25 \mathrm{M}$ & $33 \mathrm{M}$ & $17 \mathrm{M}$ & $5 \mathrm{M}$ & $1 \mathrm{~B}$ & $6 \mathrm{M}$ & $570 \mathrm{M}$ & TBD \\
\hline
\end{tabular}


Appendix D. State/PBF Allocation by Dollar Amount

\begin{tabular}{|c|c|c|c|c|c|c|c|c|c|c|c|c|c|c|c|}
\hline & AK & $\mathrm{FL}$ & IL & IN & MI & MN & MS & MO & NM & $\mathrm{NV}$ & ND & $\mathrm{OH}$ & SD & $\mathrm{TN}$ & $T X$ \\
\hline $\begin{array}{l}\text { Total Credit Hrs/ } \\
\text { Course Completion }\end{array}$ & $2.1 \mathrm{M}$ & & $2.4 \mathrm{M}$ & & & & $27.9 \mathrm{M}$ & $5 \mathrm{M}$ & $11.5 \mathrm{M}$ & & $5 \mathrm{M}$ & $330 \mathrm{M}$ & & $900 \mathrm{k}$ & $\mathbf{X}$ \\
\hline Time to Degree & & $5 \mathrm{M}$ & & $27.45 \mathrm{M}$ & & & & $5 \mathrm{M}$ & & $1.9 \mathrm{M}$ & & & & $1.2 \mathrm{M}$ & $\mathbf{X}$ \\
\hline Transfer Rates & & & & & & & & & & $950 \mathrm{k}$ & & & & $600 \mathrm{k}$ & $\mathbf{x}$ \\
\hline Degrees Awarded & $4.2 \mathrm{M}$ & $6 \mathrm{M}$ & $2.4 \mathrm{M}$ & $18.3 \mathrm{M}$ & 14400 & $10.4 \mathrm{M}$ & $620 \mathrm{k}$ & $5 \mathrm{M}$ & $3.63 \mathrm{M}$ & $7.6 \mathrm{M}$ & & $550 \mathrm{M}$ & & $1.5 \mathrm{M}$ & $\mathbf{x}$ \\
\hline Minority Students & $10.5 \mathrm{M}$ & & $2.4 \mathrm{M}$ & & & & & & & & & & & & $\mathbf{x}$ \\
\hline Low-Income "at risk" & $8.4 \mathrm{M}$ & $3 \mathrm{M}$ & $2.4 \mathrm{M}$ & $9.15 \mathrm{M}$ & & $10.4 \mathrm{M}$ & $620 \mathrm{k}$ & & $4.95 \mathrm{M}$ & $2.85 \mathrm{M}$ & & & & & $\mathbf{X}$ \\
\hline STEM Credentials & $6.3 \mathrm{M}$ & $2 \mathrm{M}$ & $2.4 \mathrm{M}$ & $6.1 \mathrm{M}$ & 14400 & $10.4 \mathrm{M}$ & & & $3.63 \mathrm{M}$ & $2.85 \mathrm{M}$ & & *bonus & $3 \mathrm{M}$ & & $\mathbf{X}$ \\
\hline External Research \$ & & & & & 14400 & & $620 \mathrm{k}$ & $5 \mathrm{M}$ & & $1.9 \mathrm{M}$ & & & $3 \mathrm{M}$ & $600 \mathrm{k}$ & $\mathbf{x}$ \\
\hline $\begin{array}{l}\text { Graduates employed or } \\
\text { continuing education }\end{array}$ & & & & & & $10.4 \mathrm{M}$ & & & $660 \mathrm{k}$ & & & & & & \\
\hline $\begin{array}{l}\text { Degrees focused on } \\
\text { State strategic plan }\end{array}$ & & $2 \mathrm{M}$ & & & & & & & & & & & & & \\
\hline Cost per completion & & & & & & & $620 \mathrm{k}$ & $5 \mathrm{M}$ & & & & & & & \\
\hline Remedial courses & & & & & & & & & & & & & & & \\
\hline Retention rates & & & & & & $10.4 \mathrm{M}$ & & & & & & & & & \\
\hline
\end{tabular}


Appendix E. State/PBF Ratio

\begin{tabular}{|c|c|c|c|c|c|c|c|c|c|c|c|c|c|c|c|c|c|c|c|c|c|}
\hline Metric & AK & State & PFB & FL & State & PFB & IL & State & PFB & IN & State & PFB & MI & State & PFB & MN & State & PFB & MS & State & PFB \\
\hline 1 & $2.1 \mathrm{M}$ & $406 \mathrm{~m}: 1$ & 20m:1 & & & & $2.4 \mathrm{M}$ & & $3 \mathrm{~m}: 1$ & & & & & & & & & & $27.9 \mathrm{M}$ & $35 \mathrm{~m}: 1$ & $1.1 \mathrm{~m}: 1$ \\
\hline 2 & & & & $5 \mathrm{M}$ & $780 \mathrm{~m}: 1$ & $4 \mathrm{~m}: 1$ & & & & $27.45 \mathrm{M}$ & $62 \mathrm{~m}: 1$ & $2 \mathrm{~m}: 1$ & & & & & & & & & \\
\hline \multicolumn{22}{|l|}{3} \\
\hline 4 & $4.2 \mathrm{M}$ & $403 \mathrm{~m}: 1$ & $10 \mathrm{~m}: 1$ & $6 \mathrm{M}$ & $650 \mathrm{~m}: 1$ & $3 \mathrm{~m}: 1$ & $2.4 \mathrm{M}$ & & $3 \mathrm{~m}: 1$ & $18.3 \mathrm{M}$ & $93 \mathrm{~m}: 1$ & $3 \mathrm{~m}: 1$ & 14400 & & & $10.4 \mathrm{M}$ & $137 \mathrm{~m}: 1$ & $5 \mathrm{~m}: 1$ & $620 \mathrm{k}$ & $1,569: 1$ & 50k:1 \\
\hline 5 & $10.5 \mathrm{M}$ & $81 \mathrm{~m}: 1$ & $4 \mathrm{~m}: 1$ & & & & $2.4 \mathrm{M}$ & & $3 \mathrm{~m}: 1$ & & & & & & & & & & & & \\
\hline 6 & $8.4 \mathrm{M}$ & $101 \mathrm{~m}: 1$ & $5 \mathrm{~m}: 1$ & $3 \mathrm{M}$ & $1.3 \mathrm{~b}: 1$ & $7 \mathrm{~m}: 1$ & $2.4 \mathrm{M}$ & & $3 \mathrm{~m}: 1$ & $9.15 \mathrm{M}$ & $186 \mathrm{~m}: 1$ & $7 \mathrm{~m}: 1$ & & & & $10.4 \mathrm{M}$ & $137 \mathrm{~m}: 1$ & $5 \mathrm{~m}: 1$ & $620 \mathrm{k}$ & 1,569:1 & 50k:1 \\
\hline 7 & $6.3 \mathrm{M}$ & $135 \mathrm{~m}: 1$ & $7 \mathrm{~m}: 1$ & $2 \mathrm{M}$ & $2 \mathrm{~b}: 1$ & 10m:1 & $2.4 \mathrm{M}$ & & $3 \mathrm{~m}: 1$ & $6.1 \mathrm{M}$ & $279 \mathrm{~m}: 1$ & 10m:1 & 14400 & & & $10.4 \mathrm{M}$ & $137 \mathrm{~m}: 1$ & $5 \mathrm{~m}: 1$ & & & \\
\hline 8 & & & & & & & & & & & & & 14400 & & & & & & $620 \mathrm{k}$ & $1,569: 1$ & 50k:1 \\
\hline 9 & & & & & & & & & & & & & & & & $10.4 \mathrm{M}$ & $137 \mathrm{~m}: 1$ & $5 \mathrm{~m}: 1$ & & & \\
\hline 10 & & & & $2 \mathrm{M}$ & $2 \mathrm{~b}: 1$ & 10m:1 & & & & & & & & & & & & & & & \\
\hline 11 & & & & & & & & & & & & & & & & & & & $620 \mathrm{k}$ & 1,569:1 & $50 \mathrm{k}: 1$ \\
\hline 12 & & & & & & & & & & & & & & & & & & & & & \\
\hline 13 & & & & & & & & & & & & & & & & $10.4 \mathrm{M}$ & $137 \mathrm{~m}: 1$ & $5 \mathrm{~m}: 1$ & & & \\
\hline
\end{tabular}

\begin{tabular}{|c|c|c|c|c|c|c|c|c|c|c|c|c|c|c|c|c|c|c|c|c|c|}
\hline & MI & State & PFB & NM & State & PFB & NV & State & PFB & ND & State & PFB & $\mathrm{OH}$ & State & PFB & SD & State & PFB & $\mathrm{TN}$ & State & PFB \\
\hline 1 & $5 \mathrm{M}$ & $193 \mathrm{~m}: 1$ & $5 \mathrm{~m}: 1$ & $11.5 \mathrm{M}$ & $76 \mathrm{~m}: 1$ & $3 \mathrm{~m}: 1$ & & & & $5 \mathrm{~m}$ & $82 \mathrm{~m}: 1$ & $1 \mathrm{~m}: 1$ & $330 \mathrm{M}$ & $6 \mathrm{~m}: 1$ & $3 \mathrm{~m}: 1$ & & & & $900 \mathrm{k}$ & & \\
\hline 2 & $5 \mathrm{M}$ & $193 \mathrm{~m}: 1$ & $5 \mathrm{~m}: 1$ & & & & $2 \mathrm{M}$ & $256 \mathrm{~m}: 1$ & $10 \mathrm{~m}: 1$ & & & & & & & & & & $1.2 \mathrm{M}$ & & $5 \mathrm{~m}: 1$ \\
\hline 3 & & & & & & & $950 \mathrm{k}$ & & & & & & & & & & & & $600 \mathrm{k}$ & & \\
\hline 4 & $5 \mathrm{M}$ & $193 \mathrm{~m}: 1$ & $5 \mathrm{~m}: 1$ & $3.63 \mathrm{M}$ & $240 \mathrm{~m}: 1$ & $9 \mathrm{~m}: 1$ & $7.6 \mathrm{M}$ & $64 \mathrm{~m}: 1$ & $2.5 \mathrm{~m}: 1$ & & & & $550 \mathrm{M}$ & $4 \mathrm{~m}: 1$ & $2 \mathrm{~m}: 1$ & & & & $1.5 \mathrm{M}$ & & $4 \mathrm{~m}: 1$ \\
\hline 5 & & & & & & & & & & & & & & & & & & & & & \\
\hline 6 & & & & $4.95 \mathrm{M}$ & $176 \mathrm{~m}: 1$ & $7 \mathrm{~m}: 1$ & $3 \mathrm{M}$ & $171 \mathrm{~m}: 1$ & $7 \mathrm{~m}: 1$ & & & & & & & & & & & & \\
\hline 7 & & & & $4 \mathrm{M}$ & $240 \mathrm{~m}: 1$ & $9 \mathrm{~m}: 1$ & $3 \mathrm{M}$ & $171 \mathrm{~m}: 1$ & $1 \mathrm{~m}: 1$ & & & & & & & $3 \mathrm{M}$ & $66 \mathrm{~m}: 1$ & $2 \mathrm{~m}: 1$ & & & \\
\hline 8 & $5 \mathrm{M}$ & $193 \mathrm{~m}: 1$ & $5 \mathrm{~m}: 1$ & & & & $2 \mathrm{M}$ & $256 \mathrm{~m}: 1$ & $10 \mathrm{~m}: 1$ & & & & & & & $3 \mathrm{M}$ & $66 \mathrm{~m}: 1$ & $2 \mathrm{~m}: 1$ & $600 \mathrm{k}$ & & \\
\hline 9 & & & & $660 \mathrm{k}$ & & & & & & & & & & & & & & & & & \\
\hline 10 & & & & & & & & & & & & & & & & & & & & & \\
\hline 11 & $5 \mathrm{M}$ & $193 \mathrm{~m}: 1$ & $5 \mathrm{~m}: 1$ & & & & & & & & & & & & & & & & & & \\
\hline 12 & & & & & & & & & & & & & & & & & & & & & \\
\hline 13 & & & & & & & & & & & & & & & & & & & & & \\
\hline
\end{tabular}




\section{Macrothink}

Journal of Educational Issues

ISSN 2377-2263

2015, Vol. 1, No. 2

Appendix F. 2014 Operating Budget/State Appropiation of 3 University Systems in Texas

\begin{tabular}{|c|c|c|}
\hline Texas & Operating Budget/Revenue & State Appropriation \\
\hline Tarleton State University & $\$ 155,430,411.00$ & $\$ 34,776,026.00$ \\
\hline Texas A\&M International University & $\$ 107,668,580.00$ & $\$ 29,729,302.00$ \\
\hline Texas A\&M University & $\$ 1,352,072,480.00$ & $\$ 252,631,564.00$ \\
\hline Prairie View A\&M University & $\$ 168,738,756.00$ & $\$ 42,769,684.00$ \\
\hline Texas A\&M University at Galveston & $\$ 58,230,775.00$ & $\$ 16,679,368.00$ \\
\hline Texas A\&M University-Central Texas & $\$ 30,276,810.00$ & $\$ 12,043,870.00$ \\
\hline West Texas A\&M University & $\$ 132,575,722.00$ & $\$ 26,870,459.00$ \\
\hline Texas A\&M University-Commerce & $\$ 162,816,970.00$ & $\$ 36,069,589.00$ \\
\hline Texas A\&M University-Corpus Christi & $\$ 173,839,270.00$ & $\$ 43,888,091.00$ \\
\hline Texas A\&M University-Kingsville & $\$ 142,726,278.00$ & $\$ 32,457,748.00$ \\
\hline Texas A\&M University-San Antonio & $\$ 40,005,484.00$ & $\$ 18,064,879.00$ \\
\hline Texas A\&M University-Texarkana & $\$ 35,368,896.00$ & $\$ 16,183,477.00$ \\
\hline The University of Texas at Arlington & $\$ 353,898,263.00$ & $\$ 15,108,252.00$ \\
\hline The University of Texas at Austin & $\$ 1,609,600,000.00$ & $\$ 67,112,823.00$ \\
\hline The University of Texas at Brownsville & $\$ 56,800,979.00$ & $\$ 8,998,602.00$ \\
\hline The University of Texas at Dallas & $\$ 329,991,128.00$ & $\$ 8,192,924.00$ \\
\hline The University of Texas at El Paso & $\$ 227,726,454.00$ & $\$ 21,196,489.00$ \\
\hline The University of Texas at San Antonio & $\$ 294,894,903.00$ & $\$ 21,324,646.00$ \\
\hline The University of Texas at Tyler & $\$ 51,873,585.00$ & $\$ 7,850,763.00$ \\
\hline The University of Texas of the Permian Basin & $\$ 29,424,633.00$ & $\$ 1,464,756.00$ \\
\hline The University of Texas-Pan American & $\$ 134,583,383.00$ & $\$ 29,884,992.00$ \\
\hline University of Houston & $\$ 289,016,320.00$ & $\$ 141,617,290.00$ \\
\hline University of Houston-Clear Lake & $\$ 94,233,214.00$ & $\$ 24,451,405.00$ \\
\hline University of Houston-Downtown & $\$ 115,833,219.00$ & $\$ 21,783,611.00$ \\
\hline
\end{tabular}


Appendix G. Performance-Based Funding Criteria Definitions

$1=$ Total credit hrs/course completion;

$2=$ Time to degree;

$3=$ Transfer rates;

$4=$ \# of degrees awarded;

5 = Minority students;

$6=\#$ low income $/ 1^{\text {st }}$ generation graduates $/$ at risk;

$7=$ STEM credentials;

$8=$ External research $\$$;

$9=$ Graduates employed or continuing;

$10=\#$ of degrees focused on state strategic plan;

$11=$ Cost per completion;

$12=$ Remedial courses;

$13=$ Retention rates.

\section{Copyright Disclaimer}

Copyright for this article is retained by the author(s), with first publication rights granted to the journal.

This is an open-access article distributed under the terms and conditions of the Creative Commons Attribution license (http://creativecommons.org/licenses/by/3.0/). 